\title{
The Effect of Marketing Mix 4P Towards Marketing Product Performance Of Tenun Ikat Small Industry In Bandar Kediri
}

\author{
Ana Komari* \\ Faculty of Engineering \\ Kadiri University, Indonesia. \\ ana@unikkediri.ac.id
}

\author{
Lolyka Dewi Indrasari \\ Faculty of Engineering \\ Kadiri University, Indonesia. \\ lolyka@unik-kediri.ac.id \\ Affif Yudha Tri Pariyanto \\ Faculty of Engineering \\ Kadiri University, Indonesia. \\ afiff@unik-kediri.ac.id
}

\author{
Heribertus Budi Santoso \\ Faculty of Engineering \\ Kadiri University, Indonesia \\ heribertus@unik-kediri.ac.id
}

\begin{abstract}
Customers' needs are increasing, and there is make more competition with similar products. In this case, it can bead dressed in marketing concept, it means a business must has a strategy to achieve objectives and provide satisfaction customers and provide of the results form of salaries to business developers. Every business running by a developer must have an effort, have a concept of strategy that can carry out activities of adaptation to the environment that currently continues to experience changes such as creating similar products without innovating. The purpose of this study was to determine the effect of 4P (Product, Place, Price, Promotion) marketing mix on marketing product performance of the tenun ikat industry in Bandar Kediri. Then, respondents were searched for filling out the questionnaire. At the end of the calculation, results on the variables $X 1$ and $X 4$ were stated. They do not have a standard assumption deviate because of each variable values on tolerance $<0.10$ and VIF value $<\mathbf{1 0 . 0}$. Then, at X2 (distribution place) and X3 (price is not a problem in getting the product).
\end{abstract}

Keywords-Customers, Product, Tolerance, $4 P$

\section{INTRODUCTION}

With the more convenient access to technology in this era, marketing activity will continue to be easily accessible and easily identified by customers on products that will be used. Then, the competition is getting tighter, and a product when will market must know what the customerwants[1]. Based on this statement, the 4P role is vast and influential. In the price, each customer wants the cost of the product to be purchased and can beaffordaily[2]. The location of the company's $t$ must be easily accessed by customers to facilitate the purchase process. A product, according to Ali Hasan, 2008 in [3] a product what is needed by customers is getting more and competition with similar products increased, so in this case, it can be responded in marketing concept must have a strategy to achieve the goal of marketing and giving satisfaction for customers and giving results form of salaries for business developers [4]. In marketing activities, the company will try to achieve its objectives. It will affect the products to be marketed, the price to be agreed between the customer and company, then the place where used to marketing the product, and the company way in attracting purchasing power by giving promotions to customers to increase customer interest [5][6]. According to Kotler and Keller, 2007 in [7] referred to the marketing mix is ways it can determine the objectives of the company to be achieved, then, in this case, it takes time to determined by the company in achieving its goals in the marketing mix[8]. The purpose of this study was to assess the effect of the 4P (Product, Place, Price, Promotion) marketing mix on marketing product performance of the Tenun ikat industry in Bandar Kediri. According to Kotler (2002), in [9]in the marketing concept, the volume of sales is one of the benefits and profits from the sales volume for the satisfaction consumers of the product bought. Every business running by a developer must have an effort, including:

Having a concept of strategy to adapt activities in the environment that having continuous changes such as the ease of creating similar products without innovating [10].

Perform activities related to change that have a direction to the creation of positive values for users[11].

Giving a touch of innovation if it has a similar product, observe the product to be marketed to determine the high of the purchasing power, and classify groups of buyers to assess product specifications quickly are expected by customers [1].

Knowing the quality of human resources used to produce the products and to find out how reliable human resources are used in conducting operations, the tools, or skills used [12].

Related to this research, it has the aim of knowing the effect partially and jointly on 4P (Product, Place, Price, Promotion)

Marketing performance, according to [13], marketing performance is a point that has a cover about the existence of marketing activities, decisions, and programs to measure 
performance. As a result of increased marketing performance, profitability, and marketing productivity will also increase [14]. Marketing performance is a concept for measuring the market performance of a product. Every company has an interest in achieving market performance from its products; the company's performance is able to compete in the world of business competition. According to Menurut [15], improving marketing performance requires market orientation variables, customer relationship management, and product innovation. Performance in marketing, if it does not have these variables, will cause symptoms of unstable marketing performance.

According to Kotler and Keller [16] in[17] in the marketing mix, there are $4 \mathrm{P}$, such as:

A product is between stuff or services needed by customers to fulfill needs. In work experiencing phase called product life cycle, it means when a product is known to the company have to marketed product to grow and be recognized by the public. So, in this case, the product will undergo a phase of maturity because the product already has many customers. If this product does not have innovation, it will automatically lose by competitors. Because indirectly, when the product is widely known, competitors will learn the specifications of the product to conduct the competition[18].

In marketing products related to the situation, it is the way of distributing a product that is used to promote the development known to the public and easy access when making a purchase[19]. From this distribution channel, the location must be easily accessible using any vehicle, and they have a warehouse that is used to store the product if it is still in a period then determining the location of the work must have a level of comfort for customers who want to get products from the company[20][16].

The products that have been marketed, the price will affect it. In this case, the provision of pricing for a product has a role that gives influence to customers to buy and become an eternal customer[21]. From the price provided, the customer must get satisfaction, and the company needs to get the profit set by the company rules. Pricing activities are significant in symbolizing the products that will be consumed by customers[22].

A product needs to be introduced to the public to know the market response. In this case, the ways of advertising are fundamental when the product is added to the market[23]. The work being promoted will be easy to know how much the customer responds to the product. With the promotion of the product, it will be quickly recognized, and the most important thing is that a product must be able to appeal to customers[19].

The research framework is as follows:

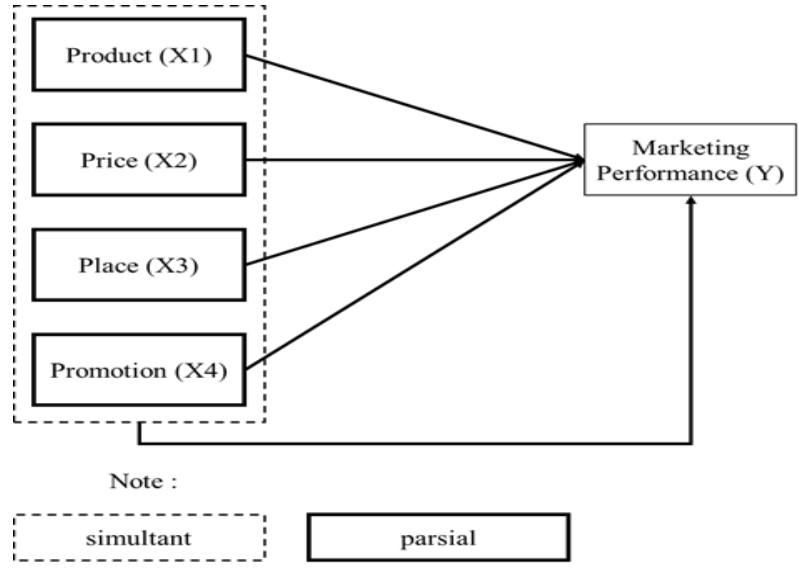

Figure 1. Framework

\section{METHOD}

This research uses a quantitative approach to explain the relationship between 4P (Product, Price, Place, Promotion) in marketing performance. The population and sample in this study used saturated sampling; the number of pieces was the population that filled out the questionnaire as a primary data collection related to $4 \mathrm{P}$, namely customers from the Tenun Ikat Medali Mas industry, Bandar Kidul. Questionnaires used is by using a Likert scale of 1 (disagree), 2 (less agree), 3 (accept) to 4 (strongly agree). This study conducted a validity test and reliability test to find out whether the questionnaire data is valid or not. If there is invalid and reliable data, it does not need to continue. Assuming the data was accurate if $\mathrm{R}$ arithmetic > $\mathrm{R}$ critical, while the data was supposed to be stable if the $\mathrm{R}$ count $<r$ essential with the number of respondents were 40 . Then the classics sumption test was performed with the normality test stage to find out whether each variable has a normal distribution or not, then the heteroscedasticity test to find out the inequality of variations on the variables in the observations that occur; the next step is a test to detect whether there are pairs of independent variables that are mutually correlated with each other. After that, the regression test with the T-test used to Determine the highlevel influence independent variables on the dependent variable that can be used to make conclusions in assumption significance $\mathrm{T}<0.05$, then $\mathrm{Ho}$ is rejected, and if the significance $\mathrm{T}>$ Ho accepted.

Table 1 Operational Variables

\begin{tabular}{llll}
\hline Concept & Variable & Scale & $\begin{array}{l}\text { Score }=\text { Attitude of } \\
\text { Respondent }\end{array}$ \\
\hline $\begin{array}{l}\text { The Effect } \\
\text { of }\end{array}$ & Product $\left(\mathrm{X}_{1}\right)$ & Likert & $\begin{array}{l}1=\text { Strongly Disagree } \\
2\end{array}$ \\
Marketing & & $3=$ Disagree \\
Mix 4P & & $3=$ Agree \\
Toward & & $5=$ Strongly Agree \\
Marketing & & \\
ProductPerf & Price $\left(\mathrm{X}_{2}\right)$ & Likert & $1=$ Strongly Disagree \\
ormanceOf & & $2=$ Disagree \\
Tenun Ikat & & $3=$ Neutral \\
Small & & & $4=$ Agree \\
Industry In & & $5=$ Strongly Agree \\
Bandar & Place $\left(\mathrm{X}_{3}\right)$ & & $1=$ Strongly Disagree \\
Kediri & & Likert & $=$ Disagree \\
& & & $3=$ Neutral \\
& & & $4=$ Agree \\
& & $5=$ Strongly Agree \\
\hline
\end{tabular}




\section{Promotionn $\left(\mathrm{X}_{4}\right)$}

Perform nce $(\mathrm{Y}$

Source: Data processing, 2020)

The type and source of data in this study, namely qualitative data, is data that is presented verbally, not in the form of numbers (Semiawan, 2010). Quantitative data is data that can be measured directly, or explanations in the form of numbers according to the research topic (Whidmurni, 2017).

Primary data sources are data collected directly from research sources (Maksum, 2012). In secondary data, data is collected as a step to strengthen primary data (Maksum, 2012).

Data related to literature studies are obtained through the internet with keywords related to research topics; they can refer to reputable research journals; both journals speak Indonesian and English (Agusta, 2014).

The data analysis techniques used are as follows (Whidmurni, 2017):

1. Validity Test: Validity test with the decision value RCost> Rtable.

2. Reliability Test: Reliability test with the following intervals and criteria:

Table 2. Cronbach Alpha Intervals and Criteria

\begin{tabular}{|rr|rl|}
\hline 1 & Interval & 2 & Criteria \\
\hline 4 & $<0,200$ & 5 & Very \\
& & Low & \\
\hline 6 & $0,200-$ & 7 & Low \\
0,399 & & & \\
\hline 8 & $0,400-$ & 9 & Enough \\
0,599 & & & \\
\hline 10 & $0,600-$ & 11 & High \\
0,799 & & & \\
\hline 12 & $0,800-$ & 13 & Very \\
1,000 & & High & \\
\hline
\end{tabular}

(Source : [24])

1. Multiple Linear

Regression Test According to (Tumbuan, Mandey, \& Kakasih, 2014), the multiple linear regression equation is as follows:

$$
\mathrm{Y}=\mathrm{a}+\mathrm{b} \_\mathrm{n} X \_\mathrm{k}+\mathrm{b} \_\mathrm{n} X \_\mathrm{k}
$$

Information :

$\mathrm{Y}$ : the predicted value of $\mathrm{Y}$

$\alpha$ : constant value

bn: coefficient of determination

$\mathrm{Xk}$ : independent variable

2. T-Test

The T-test (partial) to see the extent of influence individually on the variable $(\mathrm{X})$ on the variable $(\mathrm{Y})$, with acceptance of the hypothesis, namely: $\mathrm{H} 0$ is rejected if Sig. $>0.05$ or Ttable $>$ TCount $\mathrm{Ha}$ is accepted if Sig. $<0.05$ or Tcount $>$ Ttable
3. F Test

The F test is used to determine the level of influence of the independent variable (X) simultaneously on the dependent variable ( $\mathrm{Y}$ ) using the formula:

Df1 $=\mathrm{k}-1=$ independent variable $-1=\mathrm{n}$

Df2 $=\mathrm{n}-\mathrm{k}=$ number of respondents - independent variable $=\mathrm{n}$

Ftable $>$ So, df 1 and df 2 are ndf 1 , ndf $2=\mathrm{n}$

How to compare the value of Fcount with Ftable with the following conditions:

a. If Sig <0.05 and Fcount > Ftable, then $\mathrm{H} 0$ is rejected and $\mathrm{Ha}$ is accepted. This means that simultaneously the independent variable (X) has a significant effect on the dependent variable (Y).

b. If Sig> 0.05 and Fcount < Ftable, then $\mathrm{HO}$ is accepted $\mathrm{Ha}$ is rejected. This means that simultaneously the independent variable $(\mathrm{X})$ has no significant effect on the dependent variable (Y).

4. The Coefficient of Determination.

The value of the coefficient of determination is to find out how much the explanation in the study is and how little is not explained by looking at the R Square value

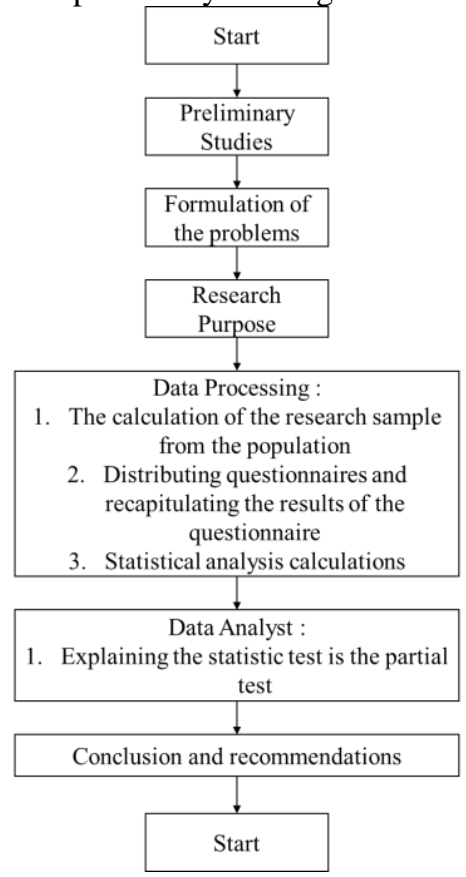

Figure 1. Methods

\section{RESULT AND DISCUSSION}

The results obtained from the statistical analysis of the validity and reliability tests are as follows:

Table 3. One- sample Kolmogorov- Smirnov Test

\begin{tabular}{lll}
\hline & & UnstandardizedResidual \\
\hline$N$ & & 40 \\
\hline Normal & Mean & .0000000 \\
\cline { 2 - 3 } Parameters $^{b}$ & Std. Deviation & .79544689 \\
\hline Most & Absolute & .087 \\
\cline { 2 - 3 } $\begin{array}{l}\text { ExtremeDiffere } \\
\text { nces }\end{array}$ & Positive & .069 \\
\cline { 2 - 3 } & Negative & -.087 \\
\hline Test Statistic & & .087 \\
\hline Asymp. Sig. (2-tailed) & $.200^{\mathrm{c}, \mathrm{d}}$ \\
\hline
\end{tabular}


From the table above, it can be seen in the A symp section. Sig (2-tailed) is worth 0,200. Which in calculations using alpha 0.05. Then, Sig. > alpha 0.05 data are declared customarily distributed, then the requirements in the regression model have been fulfilled.

From the partial T-test coefficient table, a classic assumption test can be taken, namely, the Heteroles data test, which is used to assume the $4 \mathrm{P}$ variable to influence marketing performance. So to Sig. X1 (Promotion) is worth 0.652 , X2 (Place) is worth 0.904, X3 (Product) is worth 0.144 , and $\mathrm{X} 4$ (Price) is worth 0.192. From these $\mathrm{X}$ variables, each Sig. > alpha (0.05). Then the multicollinearity test on the VIF value has an assumption if the tolerance value $>0.10$ while the VIF value $<10.0$ is stated not to occurmulti collinearity. Whereas the tolerance value $<0.10$ and VIF value $>10.0$ are stated to occurmulti collinearity. So, in this case, the variables X1, X2, X3, and $\mathrm{X} 4$ are stated do not have a standard assumption deviation because of each of the variable's values at tolerance $<0.10$ and VIF value $<10.0$.

Table 4. T-Test

\begin{tabular}{|c|c|c|c|c|c|c|c|}
\hline \multicolumn{2}{|c|}{$\begin{array}{l}\text { Unstandardized } \\
\text { Coefficients }\end{array}$} & \multicolumn{2}{|c|}{$\begin{array}{l}\text { Standardized } \\
\text { Coefficients }\end{array}$} & \multicolumn{4}{|c|}{ CollinearityStatistics } \\
\hline$B$ & Std. Error & Beta & $t$ & & Sig. & $\begin{array}{c}\text { Tolera } \\
e\end{array}$ & VIP \\
\hline (Constant) & .537 & .482 & & 1.114 & .273 & & \\
\hline Promotion & .041 & .090 & .083 & .455 & .652 & .762 & 1.313 \\
\hline Place & -.012 & .098 & -.021 & -.121 & .904 & .847 & 1.180 \\
\hline Product & .150 & .100 & .240 & 1.493 & .144 & .994 & 1.006 \\
\hline Price & -.155 & .117 & -.232 & -1.329 & .192 & .842 & 1.188 \\
\hline
\end{tabular}

Then in the Partial T-test, it has the following hypothesis assumptions:

1. $\mathrm{H} 1=$ There is an effect of promotion on marketing performance

2. $\mathrm{H} 2$ = place influence on marketing performance

3. $\mathrm{H} 3=$ There is a product effect on marketing performance

4. $\mathrm{H} 2=$ there is an effect of price on marketing performance

In this hypothesis, it is assumed, if the value of Sig. < alpha 0.05 then stated $\mathrm{H} 1, \mathrm{H} 2, \mathrm{H} 3$, and $\mathrm{H} 4$ are accepted while the value of Sig. > alpha 0.05 expressed as H1, H2, $\mathrm{H} 3$, and $\mathrm{H} 4$ were rejected. Noted that :

\section{Promotion $>0.05$ then $\mathrm{H} 1$ is accepted}

\section{Place $<0.05$ then $\mathrm{H} 2$ is rejected}

\section{Product $>0.05$ then $\mathrm{H} 3$ is accepted}

\section{Price $<0.05$ then $\mathrm{H} 4$ is rejected}

It can be concluded that in the collection of 40 respondents with the data processing above, it was concluded that the promotion variables and product variables influenced marketing performance; in this case, by the promotion, the community would know about batik products and the quality of the product was the main objective for the buyer. Buyers are more concerned about their promotions and product quality. In the place and price, a variable is not too much of a concern for the buyer because, in this case, the place does not affect marketing. After all, the product can be ordered online. The buyer does not need to think about locations, whereas for the price, the buyer already knows that the product quality has a price higher or challenging to reach by the middle class and below, if buyers from the middle class and above, a purchase price will not affect the marketing performance.

Table 5. Validity Test and Reliability Test

\begin{tabular}{|c|c|c|c|c|}
\hline $\begin{array}{l}\text { aria } \\
\text { ble }\end{array}$ & $\mathrm{R}_{\text {Count }}$ & $\begin{array}{l}\text { Descr } \\
\text { iption }\end{array}$ & $\begin{array}{l}\text { Cronbach } \\
\text { Alpha }\end{array}$ & Description \\
\hline \multirow[t]{4}{*}{$\mathrm{X} 1$} & 0,957 & Valid & 0,908 & Reliabel \\
\hline & 0,957 & Valid & & \\
\hline & 0,927 & Valid & & \\
\hline & 0,729 & Valid & & \\
\hline \multirow[t]{4}{*}{$\mathrm{X} 2$} & 0,926 & Valid & 0,870 & Reliabel \\
\hline & 0,854 & Valid & & \\
\hline & 0,866 & Valid & & \\
\hline & 0,681 & Valid & & \\
\hline \multirow[t]{4}{*}{$\mathrm{X} 3$} & 0,952 & Valid & 0,900 & Reliabel \\
\hline & 0,712 & Valid & & \\
\hline & 0,890 & Valid & & \\
\hline & 0,947 & Valid & & \\
\hline \multirow[t]{4}{*}{$\mathrm{X} 4$} & 0,883 & Valid & 0,835 & Reliabel \\
\hline & 0,872 & Valid & & \\
\hline & 0,805 & Valid & & \\
\hline & 0,763 & Valid & & \\
\hline \multirow[t]{4}{*}{$\mathrm{Y}$} & 0,974 & Valid & 0,947 & Reliabel \\
\hline & 0,974 & Valid & & \\
\hline & 0,932 & Valid & & \\
\hline & 0,867 & Valid & & \\
\hline
\end{tabular}

Based on the validity test, variables (X1), (X2), (X3), (X4), and Marketing Performance (Y) have valid results with evidence of the value of Rhitung > Rtabel, while the reliability test of these variables has a Cronbach Alpha value. $>0.60$ is declared reliable, with the Marketing Performance variable (Y), which has the highest Cronbach Alpha value. In the regression test with the following results:

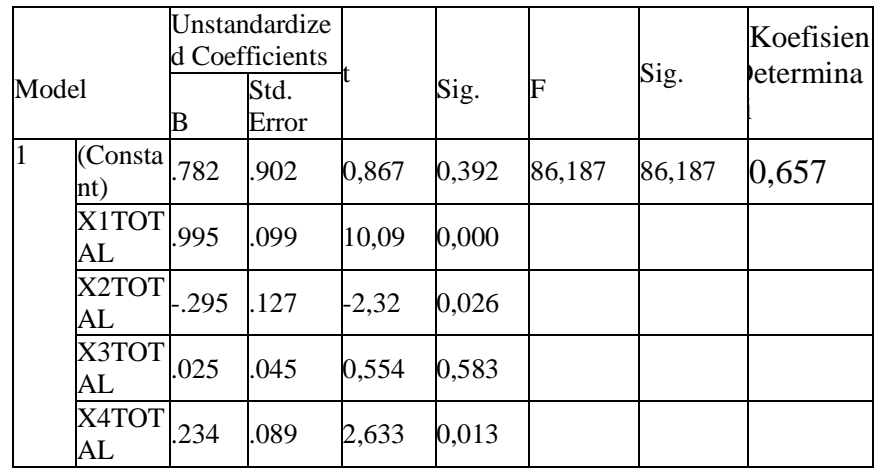

In this case, the multiple linear regression test will be constant; if $\mathrm{X} 1, \mathrm{X} 2, \mathrm{X} 3$, and $\mathrm{X} 4$ have a value of 0 units, it will have a performance impact on the factory of 0.782 . Meanwhile, if X1

Experienced an increase in activity by 0.995 , it would be more able to work. Whereas in X2, it is worth 0.995 if other 
variables are not doing activities. At X3, the value is -0.295 with a value $(-0.052)$. At $\mathrm{X} 3$, it is 0.25 if the other variables are not doing the activity, and at $\mathrm{X} 4$, it is 0.234 ; this happens if the other variables are constant. Whereas for the T-test, except the variable X3 has an influence on marketing performance, while simultaneously X1, X2, X3, and X4 have a joint influence on the marketing performance of the woven fabric. The success rate of this study is 0.657 .

\section{CONCLUSION}

Related to this research it has the aim of knowing the effect partially and jointly on 4P (Product, Place, Price, Promotion). Partially $\mathrm{X} 3$ has no effect on performance. Meanwhile, together with X, X2, X3, and X4, can perform activities in a compact and supportive manne

\section{ACKNOWLEDGMENT}

The researcher wants to support Kadiri University, especially the Engineering Faculty, for giving a chance for doing the research and composing the report.

\section{REFERENCES}

[1] N. Laely, "Analysis of the Effect of Trust and Price on Customer Loyalty Mediated Satisfaction at PT. Telkomsel in Kediri.," Econ. Manag., vol. 3(2), pp. 61-74, 2016.

[2] M. J. Baker, "Chapter 12 - The marketing mix* *This Chapter draws extensively on Baker (2006) and Baker (2007).,” M. J. Baker and S. B. T.-T. M. B. (Sixth E. Hart, Eds. Oxford: Butterworth-Heinemann, 2008, pp. 247-259.

[3] G. Suendro, "Analysis of the influence of product innovation through marketing performance to achieve sustainable competitive advantage. Diponegoro University," 2010

[4] T. Andjarwati, "The Effect of Fishermen's Moral Economy and Entrepreneurship on Fishermen's Household Economic Behavior in Kenjeran Beach, Surabaya, East Java.," 2017.

[5] A. Komari, "ICSS."

[6] D. Bojanic, "Chapter 3 - Hospitality marketing mix and service marketing principles," in Handbooks of Hospitality Management, H. Oh and A. B. T.-H. of H. M. M. Pizam, Eds. Oxford: Butterworth-Heinemann, 2008, pp. $59-84$.

[7] C. A. D. Selang, "Effect of Marketing Mix on Consumer Loyalty at the Fresh Mart Bahu Mall Manado," vol. 1(3), pp. 71-80, 2013.

[8] C. S. Yeu et al., "A Comparative Study on International Marketing Mix in China and India: The Case of McDonald's," Procedia - Soc. Behav. Sci., vol. 65, no. ICIBSoS, pp. 1054-1059, 2012, doi: 10.1016/j.sbspro.2012.11.370

[9] P. Kotler and G. Armstrong, Principles Of Marketing, 15th ed. Boston: Pearson UK, 2019, 2014.

[10] A. Komari, "The Influence of Environment and Managerial Capacity on Funding Decisions for Small Crafts Enterprises in East Java.," vol. 4(1), 2017.

[11] N. A. Wahab, L. F. A. Hassan, S. A. M. Shahid, and S. N. Maon, "The Relationship Between Marketing Mix And Customer Loyalty In Hijab Industry: The Mediating Effect Of Customer Satisfaction," Procedia Econ. Financ., vol. 37 , no. 16 , pp. 366-371, 2016, doi: 10.1016/s22125671(16)30138-1.
[12] S. Susilowati and I. Farida, "The Impact of Human Resource Management on Work Spirit of PT Bukit Jaya Abadi Surabay Employees," vol. 3(2), 2016.

[13] D. Arli and F. Tjiptono, "Does corporate social responsibility matter to consumers in indonesia?," Soc. Responsib. J., 2014, doi: 10.1108/SRJ-01-2013-0007.

[14] E. F. Nurpeni, "Rencana Pemasaran Klinik Eksekutif Rumah Sakit Hermina Depok dengan Pendekatan Balanced Scorecard," J. ARSI Kebijak. Kesehat., 2015, doi: 10.7454/ARSI.V1I2.2177.

[15] Nurlaely, A. Sularso, and H. Panjaitan, "Influence of Customer Relationship Management and Product Innovation on Market Orientation, Competitive Advantage in Improving the Marketing Performance of Food Industry Small Businesses In East Java," Int. J. Bus. Manag. Invent., vol. 8, no. 04, p. 13, 2019.

[16] P. Kotler, Marketing Management Volume 1. Erlangga, 2012.

[17] Repository, "Marketing Mix 4P," 2014.

[18] S. R. Nikhashemi, A. K. Tarofder, S. S. Gaur, and A. Haque, "The Effect of Customers' Perceived Value of Retail Store on Relationship between Store Attribute and Customer Brand Loyalty: Some Insights from Malaysia," Procedia Econ. Financ., vol. 37, no. 16, pp. 432-438, 2016, doi: 10.1016/s2212-5671(16)30148-4.

[19] A. Komari, "Indosat M3 Product Marketing Strategy in Kediri City Based on SWOT Analysis," 2016, vol. 3(2).

[20] C. H. Lee et al., "Marketing mix and customer equity of SPA brands:Cross-cultural perspectives," J. Bus. Res., vol. 67, no. 10, pp. 2155-2163, 2014, doi: https://doi.org/10.1016/j.jbusres.2014.04.025.

[21] J. Cha, S. Kim, and Y. Lee, "Application of multidimensional scaling for marketing-mix modification: A case study on mobile phone category," Expert Syst. Appl., vol. 36, no. 3, Part 1, pp. 4884-4890, 2009, doi: https://doi.org/10.1016/j.eswa.2008.05.050.

[22] C. Sauvage-Mar, P.-J. Naylor, J. Wharf Higgins, and H. VonBuchholz, "Way2Go! Social marketing for girls' active transportation to school," Prev. Med. Reports, vol. $14, \quad$ p. $100828, \quad 2019, \quad$ doi: https://doi.org/10.1016/j.pmedr.2019.100828.

[23] D. Halaj and Y. Brodrechtova, "Marketing decision making in the forest biomass market: The case of Austria, Finland and Slovakia," For. Policy Econ., vol. 97, pp. 201-209, 2018, doi: https://doi.org/10.1016/j.forpol.2018.08.009.

[24] D. P. Andriani, "Validitas dan reliabilitas skala," Universitas Brawijaya. Universitas Brawijaya, Malang, pp. 1-39, 2017. 